\title{
ДО ПРОБЛЕМИ ПРАВОВОї СОЦІАЛІЗАЦІї: ДЕПРИВАЦІЯ ЯК СТАН СОЦАЛЬНОГО ВІДЧУЖЕННЯ ОСОБИ
}

\author{
ПАРУТА Олена Володимирівна - кандидат юридичних наук, доцент \\ кафедри теорії, історії та філософії права Навчально-наукового Інституту \\ права, психології та інноваційної освіти Національного університету «Львівська \\ політехніка" \\ УДК 340.12:316.61 \\ DOI 10.32782/NP.2020.4.2
}

В статье рассматриваем сочиальную депривачию как бактор, который делает невозможнъим вфббективную правовую соизиализачию, обозначает состояние отчуждения человека от общества и государства. Устойчивая сочиильная депривация въззивает деббормацию структурь самосознания человека, в правовой сфере проявляется в его противоправном поведении. Последствиями сочиальной депривации является социальная дезориентаиия, нереализованность гражданских прав, сочиальные и политические конбликты, гражданские войнъ, отсутствие терпимости к этническим и религиознъим различиям, алкоголизм, наркомания, распад семьи, преступность и насилие. Социальная депривация порождает замкнутьии круг ее асоииальньх последствий на будущее, ито несомненно требует гораздо большего внимания к данному общественному явлению как со сторонъ ученъх, так и со сторонъ правительственных и общественных институтов.

Ключевъе слова: правовая сочиализачия, соииальная депривачия, правовое воспитание, сочиальная изоляция, личность, противоправное поведение.

Постановка проблеми

Наукові дослідження у сфері правової соціалізації неможливі без переміни ставлення до ролі їі психосоціальних чинників. Теорія права нині підіймає на поверхню чимало індивідуальних проблем правової соціалізації, з-поміж яких актуалізується проблема соціального відчуження особи. Боротьба 3 соціальною депривацією порушує питання необхідності негайного створення системи соціальних інститутів, спрямованих на соціальну інклюзію. У теорії права обмеження загальновизнаних прав, дискримінація під час соціально-правової інтеграції, динамічність процесу відторгнення, горизонтально-вертикальний тип соціальної стратифікації нині відносимо до причин соціальної ізоляції особи. Запропоноване нами у статті розуміння феномену соціальної депривації дозволяє краще усвідомити чимало проблем правової соціалізації, окреслити шляхи їхнього вирішення.

\section{Аналіз останніх досліджень і публікацій}

Вагоме значення у дослідженнях проблеми соціальної депривації мають праці, що стосуються вивчення загальних питань правосвідомості, правових, соціально-психологічних особливостей правомірної та девіантної поведінки, соціально-правової активності особи. Чимало питань правової соціалізації висвітлено у працях відомих учених, з-поміж яких: С. Бостан, Т. Гарасимів, І. Жаровська, О. Зайчук, О. Іванова, I. Ільїн, Р. Кацавець, М. Кельман, А. Колодій, С. Корсун, М. Козюбра, С. Максименко, Н. Ортинська, О. Тихомирова, Ю. Шемшученко та інші.

Не вирішені раніше проблеми

Огляд наукових джерел дозволяє стверджувати про недостатнє дослідження фено- 
мена соціальної депривації. Правова соціалізація є двостороннім процесом взаємодії індивіда і суспільства, в якому обидві сторони $є$ активними та доброзичливо налаштованими. Це актуалізує потребу пошуку шляхів ефективної правової соціалізації. Соціальна ексклюзія як передвісник соціальної депривації вже нині потребує негайного реагування з боку української держави і суспільства. Належна соціальна допомога неповним та малозабезпеченим сім'ям, соціально-психологічна підтримка дітей та підлітків, якісне пенсійне забезпечення, розвиток освіти, культури та мистецтва, ефективна ресоціалізація осіб, які раніше вчиняли правопорушення, - кроки, здатні забезпечити тісний зв'язок між громадянином та державою за засадах взаємоповаги та взаємодопомоги.

Мета статті - розкрити зміст поняття соціальної депривації, наголосити на деструктивній ролі соціальної депривації в процесі реалізації програми 3 правової соціалізації населення в Україні.

\section{Виклад основного матеріалу}

Феномен депривації в теорії правової соціалізації набуває значущості позаяк виступає потужним гальмівним чинником для повноцінного соціально-правового розвитку людини.

Соціальна депривація - це відхилення індивідуальних стандартів від реальних соціальних норм суспільства і різних соціальних спільнот, що позначає значний ступінь ізоляції особи від соціуму внаслідок втрати зв'язків із навколишнім соціальним середовищем. Соціальна депривація може бути спричинена відсутністю найнеобхідніших життєвих потреб людини і позбавленням або обмеженням доступу до звичних для неї благ.

О. Красницька розглядяє депривацію як бар'єр у засвоєнні людиною соціальних ролей, формуванні властивостей і якостей, необхідних для адекватного сприйняття соціальної реальності, іï оцінки та прийняття свідомих рішень у конкретних ситуаціях. Дослідниця наголошує на тому, що не можна недооцінювати вплив депривації на становлення і соціалізацію особистості [2, с. 28].
Соціальна депривація перешкоджає засвоєнню соціокультурних цінностей, чим унеможливлює правову соціалізацію особи. Породжуючи соціальну інволюцію (з лат. involutio - згортання, регресія) як незворотний розлад цілісності особистості, провокує появу девіантної поведінки.

Соціальна депривація постає перед нами і внаслідок довготривалої соціальної ізоляції як повного чи часткового вилучення індивіда 3 соціальної структури суспільства чи суспільних процесів, створення об'єктивних умов, за яких особа не може відігравати в суспільстві значущої ролі. До соціально ізольованих слід віднести всіх тих осіб, чиє життя на противагу власному вибору, визначається мірою байдужості та жорсткістю контролю з боку інших індивідів або суспільних груп.

Соціальна депривація особи тісно пов'язана $з$ емоційною депривацією, адже, як слушно вказує Ю. Терлецька: «Емоційна сфера людини відіграє важливу роль в її життєдіяльності. Емоції та почуття впливають на функціонування всіх інших сфер психіки, визначають характер індивідуальних властивостей особистості людини та інтенсивність їх прояву в процесі поведінки і діяльності, штовхають на різні, іноді невиправдані вчинки, дії тощо» [4, с. 68]. Авторка додає, що деструктивний процес функціонування емоційної сфери психіки людини виникає внаслідок накопичення в ній негативного енергетичного потенціалу до критичної величини, з якої той починає домінувати над позитивними емоціями і почуттями, дезорганізуючи, дестабілізуючи функціонування, по-перше, емоційної сфери, по-друге, всієї психіки за допомогою впливу на психічне різних їі сфер, що призводить до зміни величини їхнього енергетичного потенціалу (інформації та ії̈ значущості). Ми погоджуємося з Ю. Терлецькою щодо того, що питання прояву психоемоційної депривації у людей різного віку та різних професій, іiї впливу на розвиток, соціалізацію, адаптацію, професійне вигоряння, креативність тощо, а також розроблення інструментарію оцінки рівня розвитку психоемоційної депривації у людей різного віку потребують подальших розвідок [4, с. 73]. 


\section{Теорія, історія держави і права, конституційне право}

Щодо природи соціальної депривації та її зв'язку $з$ іншими явищами, 3-поміж науковців поширені різні погляди. Правники шукають причину соціальної ізоляції особи в недосконалості системи законодавства, проблемах правового регулювання та реалізації права, у недосконалій роботі систем правоохоронних та судових органів. Видатні економісти соціальне виключення розглядають як закономірний наслідок тривалої економічної кризи, яка поглинає особу в аспекті iï соціального розвитку і виявляється через різні асоціальні конструкції як-от злочинність. Психологи описують явище депривації насамперед через відхилення психічного здоров'я та інші особливості внутрішнього світу людини.

Соціальна депривація - одна 3 причин конфліктів у суспільстві. Зростання соціальної напруги є наслідком невідповідності між уявленнями особи про належне (визначене культурою, законними правами) i формальним механізмом реалізації потреб, прав, можливості доступу до різного роду ресурсів (через норми законодавства, діяльність влади). Така невідповідність провокує використання альтернативних (поза нормами законодавства) форм досягнення соціальних благ. У такому контексті варто згадати наукову позицію Р. Мертона, який охарактеризував депривацію через бажання «деприваційних груп» змінити сучасну соціальну систему, що обмежує їх права, доступ до ресурсів.

Як слушно зазначає М. Карп'як, міжнародні стандарти в галузі прав людини грунтуються на ідеї участі кожної особи в суспільному житті на засадах рівності й без дискримінації. Поряд 3 цим, сучасний різновекторний глобалізаційний процес iз його суперечностями, а також численні трансформації економічних систем різних рівнів призводять до того, що значні верстви населення виявляються відчуженими від результатів суспільного розвитку, фактично «виключеними» або «відлученими» від процесів соціальних взаємовідносин, обмеженими чи позбавленими доступу до основних соціальних інститутів суспільства. Це проявляється у величезних розривах у доходах, дефіцитах участі, зокрема у спо- живанні, у ринку праці, у певних аспектах соціальної взаємодії і підтримки, що, своєю чергою, зумовлює поширення явища соціальної ексклюзії [1, с. 40-41]. Авторка вважає, що до «ексклюзованих» або «виключених» соціальних груп в основному відносяться: молодь, громадяни похилого віку, люди, котрі протягом довгого часу залишалися безробітними, особи з фізичними або психічними обмеженнями, етнічні меншини, біженці, внутрішньо переміщені особи та мігранти. Соціальна ексклюзія як явище, на думку М. Карп'як, більшого розповсюдження набуває у країнах та регіонах iз низьким ступенем розвитку інфраструктурного забезпечення, оскільки за таких умов гостріше проявляється та зростає економічна і соціальна нерівність.

В.Ткачук доводить, що до соціальної ізоляції (соціального виключення) в Україні призводять, насамперед, наслідки кризових явищ розвитку економіки в минулому. 3-поміж таких наслідків автор називає бідність, проблеми працевлаштування, особливо серед молодих людей і осіб старших за середній вік. Так само провокують збільшення чисельності соціально ізольованих осіб недоліки соціально-економічного розвитку сучасного суспільства, адже при зростанні добробуту населення виокремлюються індивіди та групи, що є виключеними 3 певних соціальних інститутів. Соціальна ізоляція, на думку В.Ткачука, прямо пов'язана з бідністю, оскільки бідність - це шлях до втрати громадянських прав. Аюдині, яка веде щоденну боротьбу за фізичне виживання, ніколи цікавитися громадським, політичним або культурним життям суспільства [5, с. 68].

Подібної, як у В. Ткачука, думки притримується О. Ревнівцева. Авторка наголошує на тому, що у 90-х роках минулого століття в Україні відбулися суттеві зміни у соціальній стратифікації суспільства, яка характеризувалася посиленою поляризацією та поширеністю низхідної мобільності. Такі зміни привертають увагу дослідників до вивчення феномену соціального виключення певних суспільних груп за ознакою матеріального забезпечення [3, с. 98]. Ми погоджуємося з О. Ревінцевою в тому, що 90-ті роки для більшості громадян принесли неспро- 
можність підтримки звичного стилю життя. Економічна криза того часу стала джерелом низхідної мобільності і сприяла поширенню соціальної депривації.

Вирішення проблеми соціального відчуження неможливе без розуміння структури сучасного суспільства. Структура нашого суспільства - є системою нерівностей, ієрархією статусів, що є неоднаковими стосовно одне до одного. Зосередження можливості управління суспільством тривалий час в руках невеликої кількості осіб, прогресійне примноження статків так званої «соціальної еліти», поєднане з масовим зубожінням більшої частини населення, посилює соціальне відчуження особи в різних, у тому числі й правовій, сферах життєдіяльності суспільства.

У правосоціалізаційному аспекті соціальну депривацію варто розглядати, виокремлюючи два основних іiі види. Першим різновидом соціальної депривації є соціальне відчуження, пов'язане 3 вродженими «ярликами» особи чи соціальної групи (національність, расова приналежність, фізичні та розумові вади тощо). Така соціальна депривація фактично сформована внаслідок дискримінації на расовому, національному чи гендерному рівнях. Це ексклюзія особи на макрорівні.

Інший підхід споглядає на соціальне виключення індивіда у вузькому розумінні (на мікрорівні). При цьому аналізується стан носіїв соціального виключення i зосереджується на специфіці прояву життєвої ситуації членів цієї групи щодо інших членів суспільства. Цей вид соціальної депривації пов'язаний з набутими статусами, тими «ярликами», які особа набуває завдяки своїм знанням, навичкам та здібностям чи недолікам упродовж свого життя. Враховуючи те, що в сучасному суспільстві саме набуті статуси відіграють ключову роль у соціально-правовій адаптації людини, причини соціальної депривації, як і шляхи ії подолання, теоретикам слід шукати насамперед у цій площиHi.

За темпоральною ознакою соціальна депривація може бути розділена на короткотривалу, довготривалу і постійну.
Аналіз соціальної депривації як деструктивного явища дозволяє виокремити їі рівні: високий, середній та низький.

Високий рівень соціальної депривації наявний, коли соціальне відчуження призводить до повної замкнутості. Характеризується ускладненою взаємодією внутрішнього світу людини із зовнішнім середовищем. Майже завжди призводить до асоціальної поведінки людини, жорстокості та безкомпромісності.

Середній рівень соціальної депривації характеризується слабкою комунікацією індивіда і соціальних систем суспільства. Взаємодія особи із зовнішнім світом за правилами останнього здійснюеться неефективно. Зі сторони особи спостерігається соціальна пасивність, страх до зміни способу життя, зміни власного правового становища.

Для низького рівня соціальної депривації хоча й властива систематична взаємодія особи і суспільства, однак чинники, які переводять діяльність особи у позаправову площину, виявляються переважаючими. Соціальна цінність життя у відповідності до вимог загальнообов'язкових правил поведінки, що встановлюються державою, видається для особи недостатньо переконливою. Як наслідок така особа за неможливості реалізації у правовий спосіб базових потреб схиляється до протиправної поведінки.

\section{Висновки}

Поняття «соціальна депривація» в теорії права порівняно нове, щодо якого можливе досить широке тлумачення. Першочергово феномен соціальної депривації позначає високий ступінь соціального відчуження особи, відсутність можливості реалізації людиною базових прав і свобод, потерпання нетерпимості щодо себе з боку інших осіб чи соціальних груп.

Найхарактернішими наслідками впливу соціальної депривації, що є значущими на етапі побудови громадянського суспільства в Україні, вважаємо погіршення психологічного здоров' я людини, зупинку соціального розвитку, появу негативних особистісних характеристик, непристосованість особи до соціально визначених норм життя суспільства. 


\section{Теорія, історія держави і права, конституційне право}

Значимість досліджуваного феномена очевидна, адже соціальна депривація - явище, пов'язане з недовірою особи до інших людей, суспільства в цілому та держави. Рівень розповсюдження та глибини соціальної депривації повинен враховуватися в процесі побудови стратегії та реалізації процесу правової соціалізації.

\section{Мiтература}

1. Карп’як М. О. Соціальна ексклюзія в умовах глобалізаційних викликів: тенденції та форми прояву в сучасному світі. Матеріали II Всеукраӥнсъкой науково-практичной конферениї «Економіко-управлінські аспекти трансбормаий та інноваиійного розвитку галузевих $і$ регіональних суспільних систем в сучасних умовах». 2020. C. 40-43. URL: http://194.44.112.14/bitst ream/123456789/7954/1/7604p.pdf

2. Красницька О.В. Депривація к соціально-педагогічна проблема. Наукові записки НдУ ім. М. Гоголя. Серія: Психолого-педагогічні наужи. 2013. №1. C. 24-28. URL: file://C:/ Users/User/Downloads/Nzspp_2013_1_7\%20 (1).pdf

3. Ревнівцева О. В. Соціальне виключення: проблеми визначення та дослідження. Аюдсъкий розвиток. 2008. С. 98-106. URL: http://dspace.nbuv.gov.ua/bitstream/ handle/123456789/8940/08-Revnizeva . pdf?sequence $=1$

4. Терлецька Ю. М. Психоемоційна депривація людини: основні аспекти. Теорія i практика сучасноӥ психологї. 2019. №5, Т1. C. 68-74. URL: http://www.tpsp-journal.kpu. zp.ua/archive/5_2019/part_1/13.pdf

5. Ткачук В. Соціальне забезпечення як передумова подолання бідності та соціальної ізоляції населення. Економіка, управління та адміністрування. №3 (89). 2019. С. 66-70. URL: file://C:/Users/User/Downloads/185188411824-1-PB.pdf

\section{References:}

1. Karpiak M. O. Sotsialna ekskliuziia v umovakh hlobalizatsiinykh vyklykiv: tendentsii ta formy proiavu v suchasnomu sviti. Materialy II Vseukrainskoi naukovo-praktychnoi konferentsii «Ekonomiko-upravlinski aspekty transformatsii ta innovatsiinoho rozvytku haluzevykh $i$ rehionalnykh suspilnykh system v suchasnykh umovakh». 2020. S. 40-43.

2. Krasnytska O.V. Depryvatsiia k sotsialnopedahohichna problema. Naukovi zapysky NDU im. M. Hoholia. Seriia: Psykholoho-pedahohichni nauky. 2013. №1. S. 24-28.

3. Revnivtseva O. V. Sotsialne vykliuchennia: problemy vyznachennia ta doslidzhennia. Liudskyi rozuytok. 2008. S. 98-106.

4. Terletska Yu. M. Psykhoemotsiina depryvatsiia liudyny: osnovni aspekty. Teoriia $i$ praktyka suchasnoi psykholohii. 2019. №5, T1. S. 68-74.

5. Tkachuk V. Sotsialne zabezpechennia yak peredumova podolannia bidnosti ta sotsialnoi izoliatsii naselennia. Ekonomika, upravlinnia ta administruvannia. №3 (89). 2019. S. 66-70.

\section{O. Paruta. \\ TO THE PROBLEM OF LEGAL SO- CIALIZATION: DEPRIVATION AS A STATE OF SOCIAL ALIENATION OF THE PERSON}

Ukraine is going through difficult times of rethinking values, changing stereotypes, and establishing the legal foundations of civil society. These processes depend on the legal education of the younger generation, the quality of communication between citizens and the state. The new model of national education is entrusted with the reorientation of the educational process to the formation of not only intellectual, but above all pro-social, productive thinking, spiritually healthy and creative personality, able to solve problems of present and future.

The main trend in the development of scientific ideas about the essence of legal socialization is the combination of basic ideas: legal socialization - is the process of entry of the individual into the legal life of society, active assimilation of socio-legal experience, adoption of legal norms, legal values, necessary for successful life in this society; the main institutions of legal socialization are the family, the system of education and upbringing; the process of legal socialization of the individual combines socially controlled purposeful processes that affect the individual with unplanned, spontaneous influences; the formation of legal consciousness of 


\section{АНОТАЦІЯ}

у статті розглядаємо сочіальну депривацію як фактор, який унеможливлюе ефбективну правову соиіалізацію, позначае стан відчуження особи від суспільства $і$ держави. Стійка сочіальна депривачія викликає деформацію структури самосвідомості особи, що в правовій сбері виявляється у протиправній поведіниі. Наслідками соиіальної депривації є соиіальна дезорієнтація, нереалізованість громадянських прав, сочіальні та політичні конблікти, громадянсъкі війни, відсутність терпимості до етнічних та релігійних відмінностей, алкоголізм, наркоманія, розпад сім'і, злочинність та насилля. Сочіальна депривація породжує замкнене коло ї асоціальних наслідків на майбутне, що безсумнівно, потребує набагато більшої уваги до иъого суспільного явища як з боку науковиів, так $i$ з боку урядових та громадських інститутів.

Ключові слова: правова соціалізачія, соціальна депривачія, правове виховання, соціальна ізолячія, особистість, протиправна поведінка.

the person is associated with the process of selfdetermination and the formation of the legal identity of the individual,comprehension of one's own social and legal status, assimilation of social roles, formation of a social position, substantiation of one's own moral choice; legal socialization - is a complex subject process that requires effective communication between the person being socialized and the social institution, which is entrusted with the function of socialization; the lack of close interaction between the individual and society on the terms of parity and mutual respect leads to the alienation of the individual from society and its order.

In the article we consider social deprivation as a factor that prevents effective legal socialization, indicates the state of alienation of a person from society and the state. Persistent social deprivation causes a deformation of the structure of self-consciousness of a person, which in the legal sphere is manifested in illegal behavior. The consequences of social deprivation are social disorientation, unrealized civil rights, social and political conflicts, civil wars, lack of tolerance for ethnic and religious differences, alcoholism, drug addiction, family breakdown, crime and violence. Social deprivation creates a vicious circle of its antisocial consequences for the future, which undoubtedly requires much more attention to this social phenomenon both by scientists and by government and public institutions.

Keywords: legal socialization, social deprivation, legal education, social isolation, personality, illegal behavior. 